\title{
Phellinins $B$ and $C$, new styrylpyrones from the culture broth of Phellinus sp.
}

\author{
In-Kyoung Lee ${ }^{1}$, Jin-Young Jung ${ }^{2}$, Young-Ho Kim ${ }^{2}$ and Bong-Sik Yun ${ }^{1}$
}

The Journal of Antibiotics (2010) 63, 263-266; doi:10.1038/ja.2010.25; published online 26 March 2010

Keywords: antioxidant activity; phellinins B and C; Phellinus sp.; styrylpyrones

Many fungi have the ability to synthesize pigments including carotenoids, quinones and styrylpyrones. Among the Aphyllophorales, the styrylpyrone pigments are strictly restricted to Hymenochaetaceae including Phellinus and Inonotus. ${ }^{1}$ It is interesting to note that several mushrooms, which belong to the genera Phellinus and Inonotus and produce styrylpyrone pigments, have been used as traditional medicines for the treatment of gastrointestinal cancer, liver or heart diseases, and stomach ailments without the presence of toxic side effects. ${ }^{2}$ Recently, the number of novel styrylpyrones with different biological activities from the fruiting body and mycelial culture of Phellinus and Inonotus spp. has been rising sharply. ${ }^{3-7}$ Previously, we reported on four major antioxidants, hispidin, hypholomine B, 3,14'bihispidinyl and 1,1-distyrylpyrylethan isolated from the culture broths of fungi Phellinus linteus and Inonotus xeranticus. ${ }^{8}$ Based on the findings of this study, it was suggested that these pigments might have an important role in the biological activity of these fungi. In addition, we recently identified new prenylated styrylpyrones, phellinins A1 and A2, isolated from the culture broth of Phellinus sp. KACC93057 ${ }^{9}$ and suggested that these were a new group of a natural polyketide-isoprenoid hybrid compounds. In a continuous search for styrylpyrone compounds from the culture broth of Phellinus sp. KACC93057P, we isolated new antioxidants, phellinins B (1) and $\mathrm{C}$ (2). ${ }^{10}$ Phellinin B consisted of a mixture of inseparable isomers with an open chain (1a), trans-hemiketal (1b) and cis-hemiketal (1c) at an approximate equal ratio and phellinin $\mathrm{C}$ was obtained as isomeric pairs of trans-ketal (2a) and cis-ketal (2b), as shown in Figure 1. In this paper, the isolation, structure determination and biological properties of compounds $\mathbf{1}$ and $\mathbf{2}$ are described.

Details of the producing organism, Phellinus sp. KACC93057P, were described in a previous paper. ${ }^{9}$ The producing organism was stationary cultured at $25^{\circ} \mathrm{C}$ for 14 days in a tissue culture bottle $(500 \mathrm{ml})$ containing $120 \mathrm{ml}$ of YGM medium (yeast extract $1 \%$, glucose $0.4 \%$ and malt extract $0.4 \%$ ). In total, 21 of the culture broth of Phellinus sp.
KACC93057P were filtered to separate the broth filtrate and the mycelium cake. The mycelium cake was extracted with 0.51 of $80 \%$ aqueous acetone. The acetone extract was filtered, and the filtrate was concentrated under reduced pressure to remove acetone. The resulting residue was extracted twice with ethyl acetate and then subjected to chromatography on a Sephadex LH-20 column where $\mathrm{MeOH}$ was used as the elution solvent. This was followed by ODS column chromatography where the product was eluted with a gradient of increasing methanol $(40-90 \%)$ in water. The antioxidant fractions, which eluted with $70 \sim 80 \%$ aqueous $\mathrm{MeOH}$, were combined and chromatographed on a Sephadex LH-20 column with $70 \%$ aqueous $\mathrm{MeOH}$ and then, finally purified by reversed-phase thin layer chromatography (TLC) developed with $70 \%$ aqueous $\mathrm{MeOH}$ to give 1 (2.5 $\mathrm{mg})$ and 2 (2.2 $\mathrm{mg})$.

Compound 1 was obtained as a yellow powder and a single peak in the HPLC profile. However, three sets of signals with the same intensities in the ${ }^{1} \mathrm{H}$ NMR spectrum suggested that $\mathbf{1}$ was a mixture of three inseparable components, $\mathbf{1 a}, \mathbf{1} \mathbf{b}$ and $\mathbf{1} \mathbf{c}$, which were present in an approximate equal ratio. Thus, extensive spectroscopic analyses were carried to determine the structure of these three inseparable compounds. The absorption peaks in the IR spectrum of 1 suggested the presence of hydroxyl $\left(3444 \mathrm{~cm}^{-1}\right)$ and conjugated carbonyl $\left(1651 \mathrm{~cm}^{-1}\right)$ groups and its UV absorption maxima at 204, 258 and $375 \mathrm{~nm}$ revealed the presence of a styrylpyrone moiety. ${ }^{4}$ The EI-MS spectrum of 1 contained an ion peak at $\mathrm{m} / z 330[\mathrm{M}]^{+}$, and the molecular formula was determined to be $\mathrm{C}_{18} \mathrm{H}_{18} \mathrm{O}_{6}$ by HR-EI-MS, suggesting that $\mathbf{1 a}-\mathbf{1 c}$ had the same molecular composition. The ${ }^{1} \mathrm{H}$ NMR and ${ }^{1} \mathrm{H}-{ }^{1} \mathrm{H}$ COSY spectra of $1 \mathrm{a}$ indicated the presence of a 1,2,4-trisubstituted benzene moiety at $\delta 6.61(\mathrm{~d}, J=8.4 \mathrm{~Hz}), 6.92$ (dd, $J=2.0,8.4 \mathrm{~Hz}$ ), and $7.00(\mathrm{~d}, J=2.0 \mathrm{~Hz})$, a trans-disubstitued double bond unit at $\delta 6.55(\mathrm{~d}, J=16.0 \mathrm{~Hz})$ and $7.24(\mathrm{~d}, J=16.0 \mathrm{~Hz})$, and a partial structure by the COSY connectivity of $\delta 3.58(\mathrm{H}-7)$ to $\delta$ $3.01 / 2.86(\mathrm{H}-8)$ and $\delta 1.20(\mathrm{H}-11)$, as depicted in Figure 2. The

${ }^{1}$ Division of Biotechnology, College of Environmental and Bioresource Sciences, Chonbuk National University, Iksan, Jeonbuk, Korea and ${ }^{2}$ College of Pharmacy, Chungnam National University, Daejeon, Korea

Correspondence: Professor B-S Yun, Division of Biotechnology, College of Environmental and Bioresource Sciences, Chonbuk National University, Iksan, Jeonbuk 570-752, Korea. 
<smiles>C=CC1C(C)c2c(cc(/C=C/c3ccc(O)c(O)c3)oc2=O)OC1(C)OC[PH3+]</smiles>

1b<smiles>C=COC</smiles><smiles>COC[C+]1CC(C)c2c(cc(C=Cc3ccc(O)c(O)c3)oc2=O)O1</smiles><smiles>C=[PH+]</smiles><smiles>COC1(C)CC(C)c2c(cc(/C=C/c3ccc(O)c(O)c3)oc2=O)O1</smiles>

$2 a$<smiles>C=C[PH+]=C</smiles>

$1 a$<smiles>CC1CC2(C)Oc3cc(/C=C/c4ccc(O)c(O)c4)oc(=O)c3C(C)(C1)O2</smiles><smiles>C=CO</smiles><smiles>COC[C@]1(C)CC(C)c2c(cc(/C=C/c3ccc(O)c(O)c3)oc2=O)O1</smiles><smiles>C=[In]</smiles><smiles>CO[C@]1(C)CC(C)c2c(cc(/C=C/c3ccc(O)c(O)c3)oc2=O)O1</smiles>

$2 b$

Figure 1 Structures of phellinins B (1) and C (2).
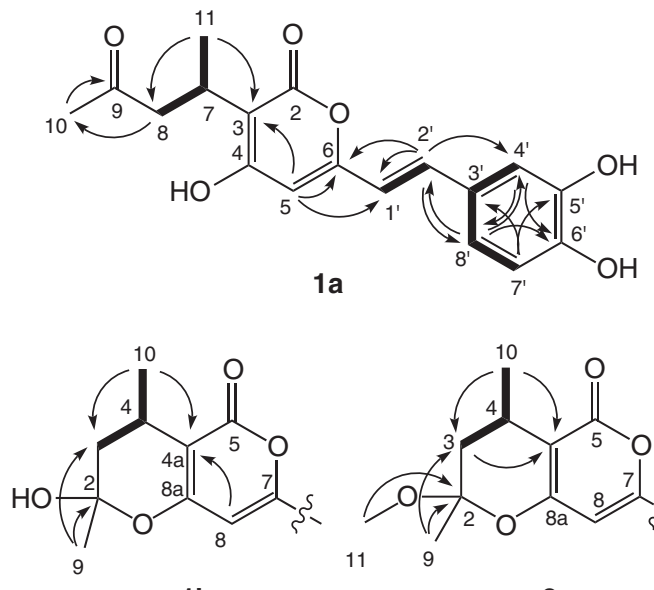

$1 b$

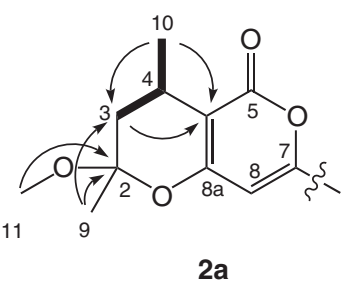

$:{ }^{1} \mathrm{H}-{ }^{-1} \mathrm{H}$ COSY
: $\mathrm{HMBC}$

Figure 2 Two-dimensional NMR correlations of compounds 1 and 2.

chemical structure of $\mathbf{1}$ was established with the aid of the HMBC spectrum. The styrylpyrone moiety was assigned by the long range correlations of $\mathrm{H}-5$ to C-3, C-6 and C-1' ${ }^{\prime}$ H-1' to C-6; H-2' to C-6, C- $1^{\prime}, \mathrm{C}-4^{\prime}$ and $\mathrm{C}-8^{\prime} ; \mathrm{H}-4^{\prime}$ to C- $6^{\prime}$ and $\mathrm{C}-8^{\prime} ; \mathrm{H}-7^{\prime}$ to C- $3^{\prime}$ and $\mathrm{C}-5^{\prime}$; and $\mathrm{H}-8^{\prime}$ to $\mathrm{C}-2^{\prime}, \mathrm{C}-4^{\prime}$ and $\mathrm{C}-6^{\prime}$, and all of the carbon chemical shifts were identical with the corresponding carbons for hispidin compounds, a representative styrylpyrone. ${ }^{4}$ The HMBC correlations from $\mathrm{H}-11$ to C7 and C-8, H-8 to C-10 and H-10 to a ketone carbonyl of C-9 revealed the presence of a pentanone moiety in 1a. This pentanone substructure was substituted to C-3 of the styrylpyrone moiety by the HMBC correlation of $\mathrm{H}-11$ to $\mathrm{C}-3$, as shown in Figure 2. Therefore, the structure of compound la was determined to be a new styrylpyrone that displayed antioxidant activity.

The ${ }^{1} \mathrm{H}$ and ${ }^{13} \mathrm{C}$ NMR spectra of $\mathbf{1 b}$ were very similar to those of $\mathbf{1 a}$. In the ${ }^{1} \mathrm{H}$ NMR spectrum, signals due to a 1,2,4-trisubstituted benzene, a trans-disubstituted double bond at $\delta 6.50(\mathrm{~d}, J=16.0 \mathrm{~Hz})$ and $7.24(\mathrm{~d}, J=16.0 \mathrm{~Hz})$, and one $\mathrm{sp}^{2}$ methine singlet at $\delta 6.01$ were evident, and these signals were in good agreement with those of the hispidin skeleton. Other proton signals including $\mathrm{H}-3, \mathrm{H}-4$ and $\mathrm{H}-9$, however, showed significantly different chemical shift values from those of 1a. In the ${ }^{13} \mathrm{C}$ NMR spectrum, the appearance of a carbon at $\delta 98.8$ (C-2) in $\mathbf{1 b}$ instead of the carbonyl carbon $(\delta 210.1, \mathrm{C}-9)$ in $\mathbf{1 a}$ was evident. The cross-peaks of $\mathrm{H}-4$ with $\mathrm{H}-3$ and $\mathrm{H}-9$ in the ${ }^{1} \mathrm{H}-{ }^{1} \mathrm{H}$ COSY spectrum indicated the presence of a partial structure that was consistent with a propyl group, as shown in Figure 2. The structure of 1b was also determined through the interpretation of the HMBC spectrum, which showed long-range correlations from $\mathrm{H}-10$ to $\mathrm{C}-4 \mathrm{a}$ and from $\mathrm{H}-9$ to $\mathrm{C}-2$ and C-3. By the process of elimination, C-2 must be connected to $\mathrm{C}-8 \mathrm{a}$ by an ethereal linkage. Therefore, the structure of $\mathbf{1 b}$ was determined to be the cyclic hemiketal form of the open chain type $\mathbf{1 b}$, as shown in Figure 1.

The ${ }^{1} \mathrm{H}$ NMR and ${ }^{13} \mathrm{C}$ NMR spectra of $1 \mathrm{c}$ were almost the same as those of $\mathbf{1 b}$, except for a slight difference in the chemical shifts of $\mathrm{H}-3$, $\mathrm{H}-4, \mathrm{H}-9$ and $\mathrm{H}-10$. Analysis of the ${ }^{1} \mathrm{H}-{ }^{1} \mathrm{H}$ COSY and HMBC spectra of $\mathbf{1 c}$ indicated that its plenary structure was the same as that of $\mathbf{1 b}$. This result suggested that $\mathbf{1 c}$ was an isomer of $\mathbf{1 b}$ in the cyclic hemiketal moiety. The relative stereochemistry was determined by comparing their ${ }^{1} \mathrm{H}$ NMR chemical shifts with warfarin analogs, which showed that the methyl protons of H-9 and H-10 were shifted 
Table $1{ }^{1} \mathrm{H}$ and ${ }^{13} \mathrm{C}$ NMR spectral data of phellinin $\mathrm{B}(1)$ in $\mathrm{CD}_{3} \mathrm{OD}$

\begin{tabular}{|c|c|c|c|c|c|c|}
\hline \multirow[b]{2}{*}{ No. } & \multicolumn{2}{|r|}{$1 a$} & \multicolumn{2}{|r|}{$1 b$} & \multicolumn{2}{|r|}{$1 c$} \\
\hline & $\delta_{C}$ & $\delta_{H}$ & $\delta_{C}$ & $\delta_{H}$ & $\delta_{C}$ & $\delta_{H}$ \\
\hline 2 & 165.2 & & 98.8 & & 99.8 & \\
\hline \multirow[t]{2}{*}{3} & 106.0 & & 41.5 & $2.16(1 \mathrm{H}, \mathrm{dd}, J=14.0,6.8)$ & 38.9 & $1.99(1 \mathrm{H}, \mathrm{dd}, J=14.0,6.8)$ \\
\hline & & & & $1.54(1 \mathrm{H}, \mathrm{m})$ & & $1.90(1 \mathrm{H}, \mathrm{dd}, J=14.0,4.4)$ \\
\hline 4 & 168.1 & & 23.2 & $2.84(1 \mathrm{H}, \mathrm{m})$ & 24.9 & $2.79(1 \mathrm{H}, \mathrm{m})$ \\
\hline $4 a$ & & & 103.8 & & 103.2 & \\
\hline 5 & 102.0 & $6.06(1 \mathrm{H}, \mathrm{s})^{\mathrm{a}}$ & 161.2 & & 161.2 & \\
\hline 6 & 159.4 & & & & & \\
\hline 7 & 25.8 & $3.58(1 \mathrm{H}, \mathrm{m})$ & 159.3 & & 159.3 & \\
\hline \multirow[t]{2}{*}{8} & 47.2 & $3.01(1 \mathrm{H}, \mathrm{dd}, J=16.4,7.6)$ & 101.5 & $6.01(1 \mathrm{H}, \mathrm{s})$ & 101.4 & $6.03(1 \mathrm{H}, \mathrm{s})$ \\
\hline & & $2.86(1 \mathrm{H}, \mathrm{dd}, J=16.4,7.6)$ & & & & \\
\hline $8 a$ & & & 160.1 & & 160.0 & \\
\hline 9 & 210.1 & & 26.8 & $1.58(3 \mathrm{H}, \mathrm{s})$ & 26.6 & $1.54(3 \mathrm{H}, \mathrm{s})$ \\
\hline 10 & 29.0 & $2.11(3 \mathrm{H}, \mathrm{s})$ & 18.4 & $1.34(3 \mathrm{H}, \mathrm{d}, J=7.2)$ & 13.6 & $1.39(3 \mathrm{H}, \mathrm{d}, J=7.2)$ \\
\hline 11 & 17.3 & $1.20(3 \mathrm{H}, \mathrm{d}, J=7.2)$ & & & & \\
\hline $1^{\prime}$ & 116.5 & $6.55(1 \mathrm{H}, \mathrm{d}, J=16.0)$ & 116.5 & $6.50(1 \mathrm{H}, \mathrm{d}, J=16.0)$ & 116.5 & $6.53(1 \mathrm{H}, \mathrm{d}, J=16.0)$ \\
\hline $2^{\prime}$ & 136.0 & $7.24(1 \mathrm{H}, \mathrm{d}, J=16.0)$ & 136.0 & $7.24(1 \mathrm{H}, \mathrm{d}, J=16.0)$ & 136.0 & $7.24(1 \mathrm{H}, \mathrm{d}, J=16.0)$ \\
\hline $3^{\prime}$ & 129.0 & & 129.0 & & 129.0 & \\
\hline $4^{\prime}$ & 114.7 & $7.00(1 \mathrm{H}, \mathrm{d}, J=2.0)$ & 114.7 & $7.00(1 \mathrm{H}, \mathrm{d}, J=2.0)$ & 114.7 & $7.00(1 \mathrm{H}, \mathrm{d}, J=2.0)$ \\
\hline $5^{\prime}$ & 146.7 & & 146.7 & & 146.7 & \\
\hline $6^{\prime}$ & 148.5 & & 148.5 & & 148.5 & \\
\hline $7^{\prime}$ & 116.5 & $6.61(1 \mathrm{H}, \mathrm{d}, J=8.4)$ & 116.5 & $6.61(1 \mathrm{H}, \mathrm{d}, J=8.4)$ & 116.5 & $6.61(1 \mathrm{H}, \mathrm{d}, J=8.4)$ \\
\hline $8^{\prime}$ & 121.7 & $6.92(1 \mathrm{H}, \mathrm{dd}, J=8.4,2.0)$ & 121.7 & $6.92(1 \mathrm{H}, \mathrm{dd}, J=8.4,2.0)$ & 121.7 & $6.92(1 \mathrm{H}, \mathrm{dd}, J=8.4,2.0)$ \\
\hline
\end{tabular}

All spectra were recorded at $400 \mathrm{MHz}$ for proton and at $100 \mathrm{MHz}$ for carbon.

aproton resonance integral, multiplicity and coupling constant $(J=\mathrm{Hz})$ in parenthesis.

downfield and upfield, respectively, in the trans form. ${ }^{11}$ Thus, compounds $\mathbf{1 b}$ and $\mathbf{1 c}$ were determined to be $\left(2 S^{*}, 4 R^{*}\right)$-trans-7(3,4-dihydroxystyryl)-3,4-dihydro-2-hydroxy-2,4-dimethylpyrano[4, 3-b]pyran-5(2H)-one and $\left(2 S^{*}, 4 S^{*}\right)$-cis-7-(3,4-dihydroxystyryl)-3,4dihydro-2-hydroxy-2,4-dimethylpyrano[4,3-b]pyran-5(2H)-one, respectively. The complete ${ }^{1} \mathrm{H}$ and ${ }^{13} \mathrm{C}$ NMR assignments of $\mathbf{1 a - 1 c}$ are described in Table 1.

Compound 2 was obtained as a yellow powder and contained a pair of peaks with similar intensity in the HPLC profile. It is interesting to note that after each peak was purified by preparative HPLC they continually converted back to a pair of peaks until they equilibrated. This indicates that compound $\mathbf{2}$ was a mixture of two inseparable isomers (2a and $\mathbf{2 b}$ ). Thus, the structure of compound $\mathbf{2}$ was determined as a mixture. Their molecular formulas were determined to be $\mathrm{C}_{19} \mathrm{H}_{20} \mathrm{O}_{6}$ by HR-EI-MS (found $m / z 344.1261[\mathrm{M}]^{+}$, calculated $\left.\mathrm{m} / z 344.1260[\mathrm{M}]^{+}\right)$. Bands because of the presence of hydroxyl $\left(3444 \mathrm{~cm}^{-1}\right)$ and conjugated carbonyl $\left(1635 \mathrm{~cm}^{-1}\right)$ groups were observed in the IR spectrum. The UV absorption maxima at $\lambda_{\max }$ $(\mathrm{MeOH})(\log \varepsilon) 204$ (4.23), 258 (3.86) and 375 (4.36) nm suggested that 2 was also a styrylpyrone analog. Analysis of the ${ }^{1} \mathrm{H}$ NMR data and ${ }^{1} \mathrm{H}-{ }^{1} \mathrm{H}$ COSY spectra of 2 provided two sets of signals that had a 1:1 ratio intensity, which suggested that the two compounds in $\mathbf{2}$ had an isomeric relationship similar to $\mathbf{1 b}$ and $\mathbf{1} \mathbf{c}$, as shown in Figure 1. The ${ }^{1} \mathrm{H}$ NMR spectrum of $\mathbf{2}$ was very similar to $\mathbf{1 b}$ and $\mathbf{1 c}$ except for the appearance of a methyl singlet at $\delta 3.26$ and 3.35 in addition to those of $\mathbf{1 b}$ and $\mathbf{1} \mathbf{c}$. The structure of $\mathbf{2} \mathbf{a}$ was determined by the HMBC spectrum, which showed critical correlations from $\mathrm{H}-11$ to $\mathrm{C}-2$, as shown in Figure 2. Other correlations from the HMBC spectrum were well-matched to the corresponding cross-peaks for compound $\mathbf{1 b} .{ }^{1} \mathrm{H}$ NMR and ${ }^{1} \mathrm{H}-{ }^{1} \mathrm{H}$ COSY spectra of $\mathbf{2} \mathbf{b}$ were very similar to those of $\mathbf{2 a}$ except for the difference in chemical shift values of $\mathrm{H}-3, \mathrm{H}-4, \mathrm{H}-10$
Table $2{ }^{1} \mathrm{H}$ NMR spectral data of phellinins $\mathrm{C}(2)$ in $\mathrm{CD}_{3} \mathrm{OD}$

\begin{tabular}{lll}
\hline No. & \multicolumn{1}{c}{$2 a$} & \multicolumn{1}{c}{$2 b$} \\
\hline 3 & $2.22(1 \mathrm{H}, \mathrm{dd}, J=14.0,6.8)^{\mathrm{a}}$ & $2.03(1 \mathrm{H}, \mathrm{dd}, J=14.0,3.6)$ \\
& $1.60(1 \mathrm{H}, \mathrm{dd}, J=14.0,12.0)$ & $1.99(1 \mathrm{H}, \mathrm{dd}, J=14.0,6.4)$ \\
4 & $2.81(1 \mathrm{H}, \mathrm{m})$ & $2.74(1 \mathrm{H}, \mathrm{m})$ \\
8 & $6.07(1 \mathrm{H}, \mathrm{s})$ & $6.10(1 \mathrm{H}, \mathrm{s})$ \\
9 & $1.55(3 \mathrm{H}, \mathrm{s})$ & $1.54(3 \mathrm{H}, \mathrm{s})$ \\
10 & $1.31(3 \mathrm{H}, \mathrm{d}, J=7.2)$ & $1.35(3 \mathrm{H}, \mathrm{d}, J=7.2)$ \\
11 & $3.26(3 \mathrm{H}, \mathrm{s})$ & $3.35(3 \mathrm{H}, \mathrm{s})$ \\
$1^{\prime}$ & $6.55(1 \mathrm{H}, \mathrm{d}, J=16.0)$ & $6.57(1 \mathrm{H}, \mathrm{d}, J=16.0)$ \\
$2^{\prime}$ & $7.24(1 \mathrm{H}, \mathrm{d}, J=16.0)$ & $7.25(1 \mathrm{H}, \mathrm{d}, J=16.0)$ \\
$4^{\prime}$ & $7.01(1 \mathrm{H}, \mathrm{d}, J=2.0)$ & $7.01(1 \mathrm{H}, \mathrm{d}, J=2.0)$ \\
$7^{\prime}$ & $6.76(1 \mathrm{H}, \mathrm{d}, J=8.4)$ & $6.76(1 \mathrm{H}, \mathrm{d}, J=8.4)$ \\
$8^{\prime}$ & $6.92(1 \mathrm{H}, \mathrm{dd}, J=8.4,2.0)$ & $6.92(1 \mathrm{H}, \mathrm{dd}, J=8.4,2.0)$ \\
\hline
\end{tabular}

All spectra were recorded at $400 \mathrm{MHz}$ for proton and at $100 \mathrm{MHz}$ for carbon. aproton resonance integral, multiplicity and coupling constant $(J=\mathrm{Hz})$ in parenthesis.

and $\mathrm{H}-11$. Analysis of the HMBC spectrum revealed that the plenary structure of compound $\mathbf{2} \mathbf{b}$ was identical to $\mathbf{2} \mathbf{a}$. This result indicates that compounds $\mathbf{2} \mathbf{a}$ and $\mathbf{2} \mathbf{b}$ have a diastereomeric relationship and the cyclic ketal forms of compounds $\mathbf{1 b}$ and $\mathbf{1 c}$, respectively. Therefore, $\mathbf{2 a}$ was determined to be (2S,4R)-trans-7-(3,4-dihydroxystyryl)-3,4-dihydro2-methoxy-2,4-dimethylpyrano[4,3-b]pyran-5(2H)-one and $\mathbf{2 b}$ was determined to be $(2 S, 4 S)$-cis-7-(3,4-dihydroxystyryl)-3,4-dihydro-2methoxy-2,4-dimethylpyrano[4,3-b]pyran-5-(2H)-one. The ${ }^{1} \mathrm{H}$ NMR spectral data of $\mathbf{2} \mathbf{a}$ and $\mathbf{2} \mathbf{b}$ are described in Table 2 .

Compounds $\mathbf{1}$ and $\mathbf{2}$ were isolated as a mixture of inseparable isomers, respectively, and thus we assessed the free radical scavenging 
Table 3 Free radical scavenging activity of phellinins B and C

\begin{tabular}{lccc}
\hline & \multicolumn{2}{c}{ TEAC $^{\mathrm{a}, \mathrm{b}}$} & \\
\cline { 2 - 3 } Compounds & DPPH & ABTS & Superoxide $\mathrm{c} / \mathrm{C}_{50}(\mu \mathrm{M})^{\mathrm{b}}$ \\
\hline Phellinin B & 0.49 & 0.46 & $16.82 \pm 2.47$ \\
Phellinin C & 5.38 & 2.06 & $61.84 \pm 4.73$ \\
Caffeic acid & 0.11 & 0.18 & $16.54 \pm 1.10$ \\
BHA & 0.34 & 0.12 & $>500$ \\
\hline
\end{tabular}

Abbreviations: ABTS, 2,2'-azinobis-(3-ethylbenzothiazoline-6-sulfonic acid); BHA, butylated hydroxyanisole; DPPH, $\alpha$,a-diphenyl- $\beta$-picrylhydrazyl.

aExpressed as $\mathrm{IC}_{50}$ of $\mu$ compound $/ \mathrm{I} \mathrm{C}_{50}$ of $\mu \mathrm{m}$ trolox.

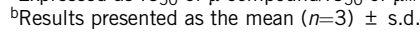

cXanthine/xanthine oxidase.

efficacy, a main property of antioxidants, of the mixture by using the DPPH (1,1-diphenyl-2-picrylhydrazyl) radical, ABTS (2,2'-azinobis(3ethylbenzothiazoline-6-sulfonate)) radical anion and superoxide radical cation scavenging assay methods. ${ }^{8}$ For DPPH and ABTS radical scavenging activity, results were expressed in terms of trolox equivalent antioxidant capacity (TEAC, $\mathrm{IC}_{50}$ of $\mu \mathrm{m}$ compound/ $\mathrm{IC}_{50}$ of $\mu \mathrm{m}$ trolox). The free radical scavenging activities of the compound mixtures are presented in Table 3. In these assays, all compounds were shown to be capable of scavenging DPPH, ABTS and superoxide radicals, in a concentration-dependent manner. Compound $\mathbf{1}$ was found to be approximately $5-10$ times higher than 2 , which contained a methoxyl group, and all of the compounds tested showed potent activity comparable with the positive control, caffeic acid and BHA (butylated hydroxyanisole).

\section{ACKNOWLEDGEMENTS}

This work was supported by a grant (20080401-034-069) from the BioGreen 21 Program of the Rural Development Administration (RDA), Republic of Korea.

1 Fiasson, J. L. Distribution of styrylpyrones in the basidiocarps of various Hymenochaetaceae. Biochem. Syst. Ecol. 10, 289-296 (1982).

2 Zaidman, B. Z., Tassin, M., Mahajna, J. \& Wasser, S. P. Medicinal mushroom modulators of molecular targets as cancer therapeutics. Appl. Microbiol. Biotechnol. 67, 453-468 (2005)

3 Lee, I. K., Seok, S. J., Kim, W. K. \& Yun, B. S. Hispidin derivatives from the mushroom Inonotus xeranticus and their antioxidant activity. J. Nat. Prod. 69, 299-301 (2006).

4 Lee, I. K. \& Yun, B. S. Highly oxygenated and unsaturated metabolites providing a diversity of hispidin class antioxidants in the medicinal mushrooms Inonotus and Phellinus. Bioorg. Med. Chem. 15, 3309-3314 (2007).

5 Lee, I. K., Kim, Y. S., Jang, Y. W., Jung, J. Y. \& Yun, B. S. New antioxidant polyphenols from the medicinal mushroom Inonotus obliquus. Bioorg. Med. Chem. Lett. 17, 66786681 (2007).

6 Lee, Y. G. et al. Src kinase-targeted anti-inflammatory activity of davallialactone from Inonotus xeranticus in lipopolysaccharide-activated RAW264.7 cells. Br. J. Pharmacol. 154, 852-863 (2008).

$7 \mathrm{Kim}, \mathrm{S}$. D. et al. The mechanism of anti-platelet activity of davallialactone: involvement of intracellular calcium ions, extracellular signal-regulated kinase 2 and p38 mitogenactivated protein kinase. Eur. J. Pharmacol. 584, 361-367 (2008).

8 Jung, J. Y. et al. Antioxidant polyphenols from the mycelial culture of the medicinal fungi Inonotus xeranticus and Phellinus linteus. J. Appl. Microbiol. 104, 1824-1832 (2008).

9 Lee, I. K., Seo, G. S., Jeon, N. B., Kang, H. W. \& Yun, B. S. Phellinins A1 and A2, new styrylpyrones from the culture broth of Phellinus sp. KACC93057P: I. Fermentation, taxonomy, isolation and biological properties. J. Antibiot. 62, 631634 (2009).

10 Yun, B. S., Lee, I. K., Kim, Y. S., Jung, J. Y. \& Jang, Y. W. Polyphenol antioxidants from the culture broth of genera Phellinus and Inonotus Korea Patent (10-0831757 B1) (2008).

11 Castleberry, B., Valente, E. J. \& Eggleston, D. S. Open-cyclic warfarin isomerism: 5hydroxywarfarin. J. Crystallogr. Spectrosco. Res. 20, 583-593 (1990). 